\title{
Macrohistory of the legal transformations in Iran from the reception of Turk-Mongolian law to the inception of legal modernization
}

\author{
OÑATI SOCIO-LeGAL SERIES VOlUME 10, ISSUE 5 (2020), 1001-1015: HistoricAL AND COMPARATIVE \\ MACROSOCIOLOGY OF MIDDLE EASTERN LEGAL SYSTEMS \\ DOI LINK: HTTPS://DOI.ORG/10.35295/OSLS.IISL/0000-0000-0000-1069 \\ RECEIVED 04 SEPTEMBER 2018, ACCEPTED 03 MAY 2019
}

\section{SAÏD AMIR ARJOMAND*}

\section{Abstract}

Two major transformations in the constitutional history of the Islamic Middle East are examined with reference to Iran. Two snapshots sketch the consequences of the reception, respectively, of the Turko-Mongolian since the first half of the fifteenth century, marked the reconciliation of Turko-Mongolian and Islamic law, and of the legal framework of the international system of modern nation-states in the nineteenth century. The turning point from the Turko-Mongolian to the modern legal transplantation is the collapse of the last Turko-Mongolian empire in world history - that of Nāder Shah (17361747). It was followed by half a century of internecine tribal warfare from which Iran emerged as a state forced to adopt Western law in the century-long course of its defensive modernization against imperialist pressure that resulted in the inception of legal modernization.

\footnotetext{
* Saïd Amir Arjomand (Ph.D, University of Chicago, 1980) has been at Stony Brook since 1978 and is Distinguished Service Professor of Sociology Emeritus, and is the Editor of the Journal of Persianate Studies. Arjomand is the author of The Shadow of God and the Hidden Imam: Religion, Political Organization and Societal Change in Shi'ite Iran from the Beginning to 1890, the University of Chicago Press, 1984; The Turban for the Crown. The Islamic revolution in Iran, Oxford University Press, 1988; and After Khomeini, Iran under his Successors, Oxford University Press, 2009. His article, "Constitutions and the Struggle for Political Order: A Study in the Modernization of Political Traditions," European Journal of Sociology/Archives européennes de sociologie, 33.4 (1992), won the Section's Award for the Best Essay in Comparative and Historical Sociology in 1993. This was followed by "The Law, Agency and Policy in Medieval Islamic Society: Development of the Institutions of Learning from the Tenth to the Fifteenth Century," Comparative Studies in Society and History, 41.2 (1999). He had recently edited two books on comparative constitutionalism: Constitutionalism and Political Reconstruction, Brill, 2007, and Constitutional Politics in the Middle East, Hart Publishing, 2008. Professor Arjomand was the Crane Inaugural Fellow in Law and Public Policy at the Woodrow Wilson School, Princeton University (2004-2005), and a Carnegie Scholar (2006 - 2008). Arjomand has published The Rule of Law, Islam, and Constitutional Politics in Egypt and Iran (edited with Nathan J. Brown, 2013), Social Theory and Regional Studies in the Global Age (2014), The Arab Revolution of 2011: A Comparative Perspective (2015), and Revolution: Structure and Meaning in World History (The University of Chicago Press, 2019). Contact details: Stony Brook University, College of Arts and Sciences. Stony Brook, NY 11794-3391. Email address: said.arjomand@stonybrook.edu
} 


\section{Key words}

Legal transplantation; Turko-Mongolian and Islamic law; modernization; shari'a and qanun (state law); legal dualism

\section{Resumen}

Se analizan dos grandes transformaciones de la historia constitucional del Medio Oriente islámico, con referencia a Irán. Dos radiografías bosquejan las consecuencias de la recepción, respectivamente, de los turco-mongoles a partir de la primera mitad del siglo XV -marcando la reconciliación del derecho turco-mongol e islámico- y del marco jurídico para el sistema internacional de los modernos Estados-nación en el siglo XIX. El punto de inflexión del trasplante turco-mongol al derecho moderno es la caída del último Imperio Turco-Mongol de Nāder Shah (1736-1747). Siguió medio siglo de guerras internas entre tribus, de las cuales emergió Irán como un Estado obligado a adoptar el derecho occidental en el curso de un siglo de su modernización defensiva contra las presiones imperialistas, lo cual dio como resultado el comienzo de la modernización jurídica.

\section{Palabras clave}

Trasplante jurídico; derecho turco-mongol e islámico; modernización; shari'a y qanun (ley del Estado); dualismo jurídico 


\section{Table of contents}

1. Introduction 1004

2. The Reception of Turko-Mongolian Law in the Fourteenth and Early Fifteenth Centuries 1004

3. Transformation of the Persianate Conception of Sovereignty and the Reception of the Idea of the Sovereign State in the Eighteenth Century 1006

4. The Reception of Modern Constitutional Law in the Nineteenth Century and the Shari 'a

5. The Qajar Dual Legal Order: Royal Administration of Justice (Divān-khāna) and the Mojtaheds' "Courts"....

6. Growth of the State Law and Privatization of the Waqf

7. The People of Iran as Subjects of the State during Legal Modernization

References 1013 


\section{Introduction}

There are at least two watersheds in the constitutional history of the Muslim world in the past millennium: the reception of Turko-Mongolian law in the fourteenth-early fifteenth centuries, and the reception of European constitutionalism in the nineteenth and early twentieth. Although the subject of this essay in the latter great transformation, a comparative, historical glance at the former transformation does not seem inappropriate as it offers a comparative historical perspective from which to view the beginnings of legal modernization in Iran.

\section{The Reception of Turko-Mongolian Law in the Fourteenth and Early Fifteenth Centuries}

The Mongol invasion of Iran disestablished Islam and the Shari'a. The Great Yasa of Chinggis Khan (d. 1227) became the law of the Turko-Mongolian military/ruling caste and leaving the Persian/Tajik subject class to their own devices under supervision of the native viziers. This dual legal system continued to prevail under the Il-Khanids - the Mongol rulers of Iran (1256-1350s) who annexed Anatolia in early fourteenth century -. The Great Yasa of Chinggis Khan (Morgan 2005) remained fully in force regarding the Turko-Mongolian ruling elite and as state law of the Il-Khanid empire in government and administration more generally. We e may, however, assume that the Shari' a half of the dual legal order became better organized under the late Il-Khanids, that is, after the conversion of Ghazan Khan and his assumption of the King of Islam (Pādshāh-e Eslām) in 1295.

Il-Khanid rule thus brought in a new, a Turkish, notion of public law: the Yasa (yasaq in Turkish) and its later derivatives, yāsāq and yasaq-nāma. In financial and public administration of medieval Muslim state, the term qānun came to mean financial and administrative regulations laid down by the ruler independently of the Shari'a. When the Mongol rulers of Iran adopted Islam, the Yasa ceded its religious character to the Shari a, and became just the law of the state. Yasa, and Yasaq thus became assimilated to Qanun. With Timur, as the Muslim restorer of Chinggis Khan's world order who styled his puppet Chinggizid king the Pādshāh-e Eslām, the Shari'a and the Yasa coexisted, roughly as the sacred law of the subject population and the state law of the ruling elite of the nomadic Turko-Mongolian empire (Manz 1988, 111-112) Conversely, the Yasa lost its Mongol connotations in the fifteenth century, and, in the forms of $y \bar{a} s \bar{a} q$ and yasaq-nāma, came to common use as code of law. Early Ottoman writers, too, praised the Yasa/Yasaq, and used its derivatives to refer to state law and public regulations (Doerfer 1963-75, Linant de Bellefonds et al. 1978/2012).

An important stage in the evolution of the legal system of Turko-Mongolian empires began in 1411/813, when Timur's son, Shahrokh, disestablished the Turko-Mongolian law, the Yasa or more precisely, "the Yarghu and the customary Töre," replacing them, according to his Shaykh al-Islam, with "the Law of the Shari a" (qānun-e shari 'at)" (Qāyeni, ff 2, 20, 128) In 1420/820, the same Shaykh al-Islam, Qāyeni, wrote a book of advice entitles Nasāyeh-e Shahrokhi, for advising the King of Islam who had taken such 
momentous step. ${ }^{1}$ The treatise is modeled on Najm al-Din Razi's pathbreaking Sufi treatise on kingship or sovereignty in which the "[spiritual] wayfaring (soluk)" of the king is presented as the way to save Islam from the Mongols ${ }^{2}$ (Arjomand, forthcoming). In substance, however, it amounts to a program for an Islamic state regulated sometimes according to the letter of the Shari'a. I consider it the first systematic constitutional proposal for the Turko-Mongolian "Kings of Islam," as Shahrokh is called (Qāyeni, f. 160) modelled distantly on the Prophet-Kings of the Old Testament, and more proximately on Mohammad and the Rightly-guided Caliphs whom Qāyeni (ff. 11v-12, $127 \mathrm{v}, 261)$ expressly considered sovereign kings. The monarchy of the Prophet-Kings is indeed the prototype and most perfect form of sovereignty (saltanat) as its political ethic corresponds to "the ethics of God (akhlāq allāh)" (Qāyeni f. 12). Having cited the wellknown Tradition of the Prophet in the form: "the ruler (sultan) is the shadow of God on earth in whom anyone who is wronged (mazlum) takes refuge," he proceeds to draw the inference that "the wrong-doing/tyrannical king (pādshāh-e zālem)" is indeed "the shadow of the Satan!" (Qāyeni, f.12v).

The emergence of the qānun as state law of Turko-Mongolian empires ushered in the

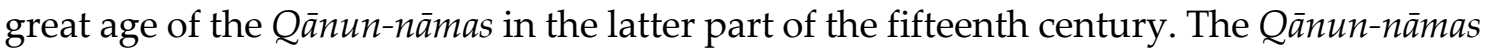
of Uzun Hasan in Iran and Mehmed II and Bayezid II in the Ottoman empire thus brought together the traditions of Persianate statecraft and that of the Turco-Mongol Khanates (Inalc1k 1978/2012). When Safavid empire became Shi ite and the Ottomans championed Sunni orthodoxy in the sixteenth century, two divergent developmental paths opened (Arjomand 2016). In the second quarter of the eighteenth century, Nāder Shah Afshār (1736-47), attempted to downplay Shi ism and bring the political and legal structure of his ephemeral nomadic empire of conquest closer to that of the Ottoman empire. But this last nomadic Turko-Mongolian empire of conquest in world history collapsed with the death of his founder in 1747, and the developmental path of politicolegal dualism in Iran was indelibly marked by the growing power of its Shi ite hierocracy.

I begin this study of modern Iran with this sketch of the fifteenth-century background for two reasons. Firstly because the reception of Turko-Mongolian state-law into the legal systems of the early-modern empires constituted as great a transformation as the reception of European constitutional law in the modern nation-states of the Middle East. So the parallel is worth studying comparatively. Secondly because there is a strong element of continuity. It is not the legal order of medieval Islam but that of the early modern Muslim empires that constitutes the legal frame for legal modernization in the Middle East.

\footnotetext{
${ }^{1}$ Qãyeni (ff. 124v-127), incidentally, deplores the disorganized state of the judiciary and the ignorance and peculativeness of the Kadis whom he advises Shahrokh to put under the supervision of the Shaykh a-Islam. 2 Three centuries later, Rāzi's formula was adopted by the Sunni jurist Fazlollāh Ruzbehān Khonji to save orthodox Islam from the heretical Shi ite Qezelbash in a treatise entitles Soluk al-moluk (The Wayfaring of Kings).
} 


\section{Transformation of the Persianate Conception of Sovereignty and the Reception of the Idea of the Sovereign State in the Eighteenth Century}

The fall of the Safavid empire in 1722 had disastrous long-term consequences for the legitimacy of the state, just as it immediately resulted in the disintegration of Iran. Nāder, a Turkman tribesman, eventually picked the pieces of the disintegrated Safavid empire and crowned himself in 1736. From the time he liberated the Iranian territory from Russian and Ottoman occupation. Nāder Shah negotiated a series of international agreements and treatises with neighboring states. ${ }^{3}$ In these, Nāder Shah acted as the representative not of the "God-given Nāderi Empire (Dawlat-e nādera-ye khodādād)" (Astarābādi 2015/1394, 395-96) but rather of the "Sovereign State of Iran (dawlat-e 'elliyaye Irān)" and of the "people of Iran (ahāli-ye Irān)" (Bayat 2004, 79-81, Astarābādi 2015/1394, 410-14, 430-31). The self-conception of Nāder's rule as a God-given empire of conquest was thus replaced by a novel one, the Sovereign State of Iran and of the people of Iran. This small terminological shift reflects the incipient incorporation Iran into the Westphalian world system sovereign states.

The meteoric rise of Nāder and the collapse of his nomadic empire of conquest after only a decade did little to instill confidence in stable monarchy and sovereignty, and the relatively short spell of peace and stability in Shiraz under Karim Khan Zand from July 1765 to February 1779 ended abruptly with his death, and "the matter of sovereignty (saltanat)" became disturbed, being divided among his infighting Zand relatives who competed in mobilizing urban militias (Shirāzi 1986, 34-44) These militias had availed themselves of the muskets of the Safavid royal slaves in alliance with tribal factions of their own and other tribes. (Shirāzi 1986, 82-87) When the turbulent four years of Ja far Khan Zand in Shiraz and Isfahan ended in his murder in January 1789, our chronicler recorded "a general revolution (enqelāb) in his armed retinue" (Shirāzi 1986, 68).

With the rapid disintegration of Nader's ephemeral nomadic patrimonial empire, the last Turko-Mongolian empire of conquest in world history disappeared, and the bumpy journey to the transformation of Iran into a modern state began. It is significant that Karim Khan called himself the Representatives of the Subjects of the puppet Safavid king and not anything like the Representative of the People of Iran. The latter terms, like the term "dawlat-e Iran" (State of Iran) remains restricted to the diplomatic context in which Iran interacts with another sovereign state in terms of the Westphalian international order (Arjomand 1988). Nor is there any immediate conceptual change when the Zand relatives of Karim Khan are eliminated by the founder of a new dynasty stemming from the northern Turkman tribe of Qajar (qājār).

Just before the rise of Nāder, the roaming Safavid prince, Tahmāsp II, had taken refuge with the Qajar tribe in Astarābād, and the Qajar leader Fath 'Ali Khan acted as his protector for a while. Nāder Shah had Fath 'Ali Khan Qajar killed in the 1730s, and a Qajar leader retaliated by participating in Nāder's murder in 1747. Karim Khan Zand had to face the successive, unsuccessful rebellions of his son, Muhammad Hasan Khan and his grandson, Hossein-qoli, and kept the latter's brother, Aqa Mohammad Khan,

\footnotetext{
${ }^{3}$ These dealt with Iranian captives and residents abroad, and lastly the recognition of the Shi ite branch of Islam by the Ottoman Sultan as the fifth of the Ja fari Rite or School of Law - that is, the School of Law of the $6^{\text {th }}$ Shi ite Imam, Ja far al-Sādiq (d. 765).
} 
who had been castrated by an Afsharid pretender, hostage in his capital, Shiraz. Upon Karim Khan's death, Aqa Mohammad Khan fled to Astarābād and gradually gained control of the surrounding regions in northern Iran. He finally eliminated Karim Khan's nephew, Lotf-'Ali Khan in 1794, and captured Shiraz, appointing the defecting Zand official, Hajji Ebrāhim (d. 1801) who became his chief minister.

The matter of sovereignty was disturbed indeed during the Zand-Qajar interregnum (1779-1794). One of the Zand bureaucrats in Shiraz who entered the service of the new Qajar dynasty through Hajji Ehrāhim was commissioned to write the history of this turbulent period for his new monarch. His chronicle of the disturbance of sovereignty in this period is poignant due to his evident sympathy for the old dynasty he had served. He dutifully recited Q. 3.25: "He giveth sovereignty (mulk) to Whom he wills and empowers whom he wills, and he takes away sovereignty from whomever he wills, and debases whom he wills," but with an emphasis on the second part, making the postSafavid eclipse of sovereignty to the wrath of God. (Shirāzi 1986, 29-30) He gives a sympathetic account of the rule of Lotf 'Ali Khan Zand, but ruminates that according to the will of God, the "eternal possessor of sovereignty (malik al mulk)," fortune favored the new Shadow of God and required the overthrow of the Zand dynasty (Shirāzi 1986, 78).

No wonder the legitimacy of the new dynasty remained shaky. Aqa Mohammad Khan (d. 1797) minted coins in the name of the Hidden Imam and an obscure Safavid princes (Amanat 2017, 162), and yet again with no name for any sovereign. (Kondo 2019) He wore the sword of the founder of the Safavid empire for his coronation, and he and his nephew and successor, Bābā Khan, ascended the throne as Fath 'Ali Shah (1797-1834) and concocted a syncretic and unconvincing basis for his legitimacy, making the unflattering claim that he and his father were the offspring of a concubine already pregnant concubine given by the Safavid Shah Soltān-Hossein to Fath 'Ali Khan and thereby adopting the epithet Safavid-Qajar (Arjomand 1983). More consequentially, he reaffirmed and consolidated his uncle's alliance with the mojtaheds (authoritative jurists) of the Shi ite hierocracy which had become fully independent of the rulers of the sevendecade post-Safavid interregnum. This alliance was the Qajar's remedy for their legitimacy deficit and created a new dualistic structure of authority in nineteenthcentury Iran in which the Shah was the head of the state while a handful of mojtaheds constituted an independent Shi ite hierocracy. (Arjomand 1984) What follows in this paper is a sketch of Shi ite Iran's legal structure in the nineteenth century within the frame of its distinctive state-hierocracy dualism that has no parallel in the Sunni Muslim world. It should be noted that the Qajar "state" consolidated by it Fath 'Ali Shah was a patrimonial monarchy. He divided the provinces and major cities among some of his over one hundred sons, described by an English traveler as "a race of royal drones, profligate and depraved, and the most noxious to their country" (cited in Arjomand 1988, 25). Despite the judiciary reforms to be discussed below, it structurally remained an unreconstructed patrimonial monarchy to the end of the nineteenth century. In the 1880s, three of Nāser al-Din Shah's (1848-1896) sons governed eleven of Iran's fourteen provinces (Ettehadieh 1989, 54).

To summarize what I have said in this section: the collapse of the centralized Safavid empire and that of the Nāder's nomadic empire of conquest in the eighteenth century 
mean that Iran entered the nineteenth century with the traditional notions of sovereignty and the state badly shaken. When signing the treaty of Finkenstein with Napoleon against Russia in 1807, and much more forcefully the humiliating Treaties of Golestan (1812) and Turkamanchai (1828) with Russia after the Perso-Russian wars, Iran becomes incorporated into the Westphalian international order as a sovereignty and embarks on a program of defensive modernization that ended in failure, however. This failure can in no small measure be attributed to the disasters of the eighteenth century.

\section{The Reception of Modern Constitutional Law in the Nineteenth Century and the Shari' a}

I have mentioned the Timurid Shahrokh's Shaykh al-Islam celebration of the abolition of the Yasa in early fifteenth century as the occasion for assimilating the Mongolian public and customary law into the older familiar concept of qānun, and its Islamicization by coupling it with the sacred law into a compound term, the Law of the Shari a (qänun$e$ shari'at/ qänun-e shar'). The same terminology and concept is used by the early exponents of modern constitutionalism in Iran in the 1970s. In a brief 10-article draft/sketch for the constitution of Iran aired in 1871 during the reformist Ministry of Mirza Hossein Khan Moshir al-Dawla (Sepahsālār) by Yusof Khan Mostashār al-Dawla, and an influential reformer and formerly Iran's Chargé d'Affaires in Paris, accordingly envisions the formation of two assembly to regulate the "Laws of the Shar ia" (qavannine Shari 'at)" enact some regulations in public law (siyāsat-e modon, literary civic politic) (Pāshāzāda 2013/1392, 98).

Mostashār al-Dawla is also the author of the first constitutional treatise in Persian that was published a little earlier and formed the basis for his draft constitution. It had been entitled Ruh al-islām (the spirit of Islam) in manuscript, but it was published under the secular title of Yek kalama (One Word). To explain the original title, Mostashār wrote to a fellow reformist thinker that he had found "proofs for all the means of progress and civilisation (the French word transliterated) in the Holy Koran and authentic hadiths so that they would no longer say this or that is against the normative order ( $\left.\bar{a}^{\prime} i n\right)$ of Islam or that the normative order of Islam is the obstacle to progress and civilisation" (Pāshāzāda 2013/1392, 38).

Mostashār al-Dawla's assimilation of the notion of sovereignty in European constitutional law was, however, conceptually more problematic than the earlier reconciliation of Turko-Mongolian and Islamic law by the Timurid and Ottoman jurists. The reason for his awkward and problematic reconciliation of the modern notion of sovereignty and Islam may well be that he was more familiar with the Persianate traditional (Aristotelian) political thought, which he refers to as siyāsat-e modon/civic politics, than with Islamic jurisprudence, ${ }^{4}$ for which we know him to have been heavily dependent on a younger Turkish contemporary, 'Ali Su āvi (Pāshāzāda 2013/1392, 5057).

Mostashār's mishandling of the issue of sovereignty received from nineteenth-century European constitutional law can in fact be confidently attributed to Su'āvi, the most

\footnotetext{
${ }^{4}$ Mostashār al-Dawla (1985/1364, p. 42) reconciles the Persianate political thought nad Islam by stating that "in the Shari at of Islam, civic politics is based on justice with respect to principles, and on the interest of the people with respect to its goals." (As cited in Pāshāzāda 2013/1392, 56).
} 
fundamentalist of the "Young Ottomans". Su'āvi had parted company with the modernist Young Ottoman, Namik Kemal, in rejecting Montesquieu's separation of the powers for the principle of "the unity of the Imamate" (Mardin 1962, 366), ${ }^{5}$ and by doing so, he was the first Islamic thinker to proclaim the constitutional Sovereignty of God. Mostashār al-Dawla followed him in this, reaffirming a confusion that resurfaced in the objectives resolution incorporated into the 1956 Constitution of the Islamic Republic of Pakistan and taken over by the 1979 Constitution of the Islamic Republic of Iran and further disseminated by Noah Feldman among scholars of comparative constitutionalism. For Su 'āvi, in Şerif Mardin's (1962, 373-74) words, "God was the seat of political sovereignty; the Şeriat was the instrument whereby this sovereignty was translated from the divine to the human plane; the ulema were the interpreters of this incarnation of God's sovereignty on earth; kings and viziers were only executors of the (...) fetvas of the ulema (...)". In explicating what souveraineté meant, Mostashār followed Su'àvi not only in declaring that sovereignty belongs to God but also in considering the separation of the powers of "the governor (vāli), the kadi and the fatva" purely functional (Pāshāzāda 2013/1392, 57).

Fortunately, Mostashār changed Su 'āvi's principle of "equality before the Şeriat" to "equality before the Qanun" and derived the term for legislation, qānun-gozāri, from Qanun in preference to Su 'āvi's teșri yye from Şeriat ${ }^{6}$ (Pāshāzāda 2013/1392, 52). Even more fortunately, the Iranian Constitution of 1906-7 renders the legislative power as the power to make the Qanun, muqannena, ${ }^{7}$ adopted Montesquieu's idea of the separation of power via the Belgian Constitution of 1831, and completely ignored Mostashār's idea of God's sovereignty, logically and correctly transferring sovereignty from the king to the nation without dragging in God.

\section{The Qajar Dual Legal Order: Royal Administration of Justice (Divān-khāna) and the Mojtaheds" "Courts"}

Mostashār al-Dawla's fanciful division of the powers bore no relation to the actual division of authority in Iran's structure of domination should not surprise us. What is more surprising, though, is that the division of the courts into the shar ' $i$ (religious) and 'orfi (secular, customary) courts in the Iranian Supplementary Fundamental Law of 1907, replicating that of the Ottoman Constitution of 1876, does not reflect the actual structure of judiciary organization in Iran by the twentieth century, as it was for long assumed to do (Floor 2009) In fact, recent studies by Werner (2005a, 2005b) and especially Kondo (2017) show this division to be completely misleading.

The office of the Kadi steadily decline in Iran under the Safavids after the establishment of Twelver Shi ism as its state religion in 1501 (Arjomand 1984) It virtually disappeared during the Afghan-Afshar-Zand interregnum, except perhaps as an honorific title. In early nineteenth century, the trial courts (singular, mahkama) may have been revived ad

\footnotetext{
${ }^{5}$ However, both Kemal and Su'àvi deplored the separation of the state from religion by the Mongols, the "followers of Chinggis" (Mardin 1962, 374).

${ }^{6}$ To be precise, he does so in formulating his Principle 9 on "people's participation in legislation" (Pāshāzāda 2013/1392, 42). Elsewhere, however, he follows Su 'āvi in rendering the "legislative power" as qodrat-e tashri " (Pāshāzāda 2013/1392, 46).

${ }^{7}$ Ataturk, by contrast used the term teșri yye for legislative power, and the Arab constitution also render legislation as tashri', etymologically derived from the Shari'a.
} 
hoc by some locally powerful mojtaheds (authoritative jurists) of the Shi ite hierocracy such as Mohammad Bāqer Shafti in Isfahan, ${ }^{8}$ but we do not meet the (Arabic) term mahkama often until the early twentieth century, when it is used to refer to the courts of

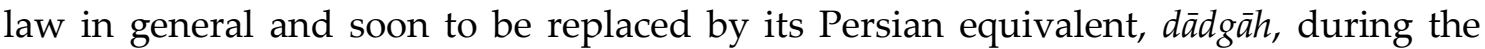
secularization of the legal system in the 1920s. Not being appointed judges, the new legal function assumed by the learned members of the Shi ite hierocracy that had grown independent of the state during the eighteenth-century interregnum was the registration of and deeds of ownership and transactions (mu 'amelāt), certification of titles and settlements and issuing of opinions on demand, and it did not extend to holding trials. Although the mojtaheds were recognized as the hokkām-shar' (hierocratic judges) and were entitled to issue binding legal verdicts (singular, hokm), and we do hear of mahkamaye shar' (religious court), especially in connection with criminal verdicts (Schneider 2006, 198), their "courts" were usually called mahzar-e shar in the singular (mahzar literally means place of presence), and can more accurately be described as registries. However, although the mahzar was not a court of trial, it could be considered a court of settlement. The Shi ite jurists appear to have stretched the scope of the contracts of settlement (mosāleha) in the light of their role in the Iranian legal structure as widely as possible to cover a very broad range of transactions including sale, donation, money lending and rent. "In summary," as Kondo $(2017,167)$ concludes from his painstaking analysis of their registers, "shari ' $a$ courts were places where legal documents, such as hokms and deeds of settlement, were issued, rather than places of trial".

Persianate political theory considered the royal administration of justice the cornerstone of the legitimacy of kingship and fundamental to the king's function of the maintenance of law and order. This remained unchanged after the fall of the Safavids. As in the Safavid period, the punishment of the four crimes (ahdāth arba $a$ ) - murder, theft, rape, injury - remained royal prerogative prerogatives (Kondo 2017, 27) The organ established for the administration of justice by the Qajar Shahs in the first half of the nineteenth century was the Divān-khāna (bureau of justice), and it heard civil cases involving the mojtaheds and their ruling on earlier stages, and in fact functioned as a court of appeals (Arjomand 2005). It remained the main organ of the administration of justice in the second half of the nineteenth century, and it continued to hear civil as well as criminal cases. The civil complaints comprised over two-thirds of its cases, and they could involve earlier the opinions ( fatva) and verdicts (hokm) of the mojtaheds, and the verdict of the Divān-khāna could be sent to a mojtahed for confirmation when appropriate (Kondo 2017, 30-35). In short, it is misleading to identify the Divān-khāna as an 'orfi court whose function would be the administration of customary law, as was implicitly done by some clerics in the constitutional debates of 1906-07 and is often done by our contemporary scholars.

After the creation of a police force under the Italian Conte di Monteforte in 1879, criminal cases were taken over by the police which was instructed to seek the opinion of the mojtaheds in hodud cases (Kondo 2017, 24-25).

In the light of our discussion of the mojtaheds' "courts," the true significance of the legal secularization in Iran from 1927 to 1939 (which has not been reversed after the revolution of 1979) was the transfer of the power of public notarization and registration of deeds

\footnotetext{
${ }^{8} \mathrm{He}$ seems to be the first person to have assumed the title of Hojjat al-Islam (Proof of Islam) in modern Iran.
} 
from the hierocracy to the state. The mojtaheds lost no strictly speaking judiciary function as those already belonged to the Divān-khāna as the organ of the royal administration of justice. The mahāzer-e shar ' were secularized as the state offices of notarization and registration of valid legal deeds (singular, daftar-e asnād-e rasmi), and the clerics who had hitherto performed this function were forced to defrock and assume civilian status and attire.

\section{Growth of the State Law and Privatization of the Waqf}

While the legal functions of the mojtaheds constituting the highest rank of the Shi ite hierocracy remained remarkably constant in the second half of the nineteenth century, the Iranian state under Nāser al-Din Shah (1848-96) embarked on legal modernization through the royal administration of justice. In 1860, he set up a traditional court of grievances (mazālem) as parallel the Divān-khāna, over which he presided every Sunday, carefully avoiding making it a court of appeals (Arjomand 2013,16). Four years later in 1864 , he devised a system of chests of justice (sanduqhā-ye 'adālat) in major cities for receiving petitions from his subjects (Schneider 2006, 34-37). In the judiciary organization by Moshir al-Dawla in June 1871, in which Mostashār al-Dawla had acted as a consultant, the Divān-khāna was renamed "House of Justice" ('Adālat-khāna), whose head was entrusted with the "removal of oppression of the governors," the classic definition of the ruler's court of grievances, the Mazālem. Nevertheless, the function of the removal of oppression was differentiated from crime, real estate and commercial cases. The Ministry of Justice ( Adliyya) was to consist of seven "councils" (singular, majles), only one of which was called the "Assembly for General Oppression" (majles-e mazālem-e 'āmma) (Pāshāzāda 2013/1392, 96-98). Finally, in 1887, yet another new/reformed judiciary ('adliyya) was inaugurated, and the aging Nāser al-Din Shah transferred his judiciary authority to it (Mohit-Tabātabā'i 1968/1347, 69-73, Arjomand $2013,16-17)$. The branch of the House of Justice dealing with petitions against oppression was called the "Council for Oppressions" (majles-e tazallomāt) (Ettehadieh 1989, 52). With this transfer of the fundamental duty of the Shah to deliver justice according to the Persianate theory of kingship to the state (dawlat) of Iran, the Qajar ruler took a significant step in transforming his patrimonial kingdom to a rechtsstaat. As we shall see, this rechtsstaat was not yet a modern nation-state.

The jurisdiction of the clerical courts of the mojtaheds in the nineteenth century covered the religious endowments (waqf), as the law of waqf was an integral part of the Shari 'a. Elsewhere I have highlighted the law of endowment as a major instrument of public policy in education and of the welfare of the poor in medieval Islamicate civilization. In instituting a Waqf according to the Islamic Law, however, rulers and their mothers, wives and high officials, acting in their private capacity as individual founders of endowments set the civic policies of Muslim patrimonial states (Arjomand 1999) Other individuals could enact Waqf for philanthropy or for the primarily for the benefit of their family members with some charitable provisions.

The observe side of the growth of the judiciary power of the state sketched above is the decline of large-scale, "public" Waqf of the royal family and grand viziers and the

\footnotetext{
9 Su'āvi, by contrast, had seen the Mazālim as the forerunner of elected assemblies in representative government (Mardin 1962, 375-76).
} 
mushrooming of small "private" of family Waqf recorded in the registries of the mojtaheds (Kondo 2017, Ch. 7). These private or predominantly non-public endowments were often administered by the members of the founders' family and for their benefit. What is interesting in the Qajar period in the extension of the patrimonial appropriation of endowments from the ruling-class families to clerical dynasties (Kondo 2017, 111-12). The merchants seem considerably less prominent as founders of endowments in Tehran than the patrician families of other Iranian cities.

No easy match can be found in the Qajar era for the grandiose Safavid endowments such as the Madrasa of the Queen Mother (Chāhār Bāgh) in Isfahan. Nevertheless, the female members of the Qajar family frequently endowed public waqfs (Kondo 2017, 101). Furthermore, the largest endowments in Tehran were founded by the Qajar kings. The Shah Mosque was built by Fath 'Ali Shah in 1830, and the Qanat-e Nāseri was built by Nāser al-Din Shah in 1856. The viziers and other bureaucrats and military officers created nearly a third of Tehran's endowments, ${ }^{10}$ including the famous Marvi madrasa (Kondo 2017, 97-107, 115-19).

\section{The People of Iran as Subjects of the State during Legal Modernization}

The prevalence of a strong sense of identity of the inhabitants of the "land of Iran" (Irānzamin) as "the people/inhabitants of Iran" (mardom-e Irān, ahl-e Irān) is well attested in the first quarter of the eighteenth century in the contemporary account of its fall of the Safavid Empire, and in the histories of Nāder Shah (1736-47) in its second quarter. The subjects of Nāder Shah's empire were still referred to as "the people/inhabitants of Iran," and there was no change in this respect. Iran's ruler in the third quarter of the eighteenth century, Karim Khan Zand (1747-79), put 'Abbās III as a puppet Safavid king on the throne but detained him in a fortress where the latter learned to make knives, while Karim Khan himself assumed the modest title of Vakil al-ra'aya (Representative of the Subjects). The less, the people of Iran remained the subjects of the nominal Safavid sovereign even for Karim Khan Zand who modestly called himself their representative.

The deepening of the involvement of Iran as a sovereign state in the nineteenth century affected the identity of its people very slowly. It made "the people of Iran" as subjects (ra 'iyyat) of the sovereign ruler of the "land of Iran" transitively the subjects of the sovereign state of Iran (dawlat-e Iran). ${ }^{11}$ It was not until 1864 that the Iranian state had passports (tazkiras) printed for "the subjects of Iran" under its own insignia ${ }^{12}$ (Pāshāzāda 2013/1392, 16).

All this was a far cry from national identity, not to say citizenship, as the Iranian state so incorporated into the international system of sovereign states was far from being a nation-state. I have said that the attempt to modernize the state at the time of consolidation of the Qajar patrimonial monarchy in early nineteenth century failed. During the next waves of state modernization in the second half of the nineteenth

\footnotetext{
10 The large endowments of Fath 'Ali Shah's vizier, Mirzā Shafi' Māzandarāni were, however confiscated by the state, as were those of a few other prominent Qajar officials (Kondo 2017, 124-25).

11 The old term for subjects (ra iyyat) continued to be applied throughout the century, both to the Iranians internally and to the subjects of foreign states (Schneider 2008, 236).

12 Until then, the Russian, British and French consulates issued their own travel documents for Iranians traveling abroad.
} 
century, Iran still only had one official gazette in Tehran, and oppositional paper began to appear only in exile. In the 1870s, Mostashār al-Dawla, who had engineered the printing of passports Iran's Consul General in Tbilisi, deplored the absence, in as important a city as the vibrant commercial Tabriz across the border, of a "national newspaper (ruznāma-ye mellati) to report the needs of the nation (mellat)" (Pāshāzāda 2013/1392, 29-30). This is one of the earliest uses of the term mellat in the secular sense, meaning the nation.

In Yek kalama, Mostashār al-Dawla proposed 19 constitutional principles reconciling European constitutional law and Islam. Despite his claim that the bill of rights implicit in some of these principles derived from the 1789 Declaration of the Rights of Man and Citizen, no word corresponding to "citizen" can be found in any of the principles; the closest terms being "the people" (mardom) and "the children of the poor". ${ }^{13}$ The term for liberty, $\bar{a} z \bar{a} d i$, by contrast, appears four times, and Mostashār al-Dawla calls France "the land of liberty" (Pāshāzāda 2013/1392, 37).

The prevalent meaning of the word mellat in Persian when Mostashār al-Dawla was writing, was the same as millet in Ottoman Turkish; it meant a religious community, and throughout Iran's Constitutional Revolution (1906-11), the religious term mellat-e shi 'a (the Shi ite community of believers) was used alongside the secular mellat-e Irann (the nation of Iran).

The latter term, mellat-e Irān (the nation of Iran), was however adopted by the Iranian Constitution (Fundamental Laws) of 1906 and 1907, and it thereby became the hallmark in modern Iranian nationalism. The above-mentioned "people of Iran" (ahl-e Irān) now constituted the nation of Iran whose sovereignty was declared in the same Constitution Iran thus became a nation-state. The subjects of the Shah now became those of the nationstate of Iran. The new term for subjects (taba' $a$ ) of the sovereign state was then coined under the impact of international law term. Literally, it meant "those under the authority [of the nation-state of Iran]". But could the subjects of the new Iranian nation-state be called citizens?

The answer is not entirely clear. The current Persian term for citizen, namely shahrvand, was coined at the inception of the reform movement under President Khatami (19972005), when it enters the discourse and ideology of dissent in the Islamic Republic of Iran. It remains to be seen when and if it becomes part of Iran's official legal vocabulary. In other words, in contrast to the double process of modernization-Sunnitization of the Iranian constitutional state, there has been no modernization of constitutional rights and no "human rights revolution." 14

\section{References}

Amanat, A., 2017. Iran: A Modern History. New Haven, CT: Yale University Press.

\footnotetext{
${ }^{13}$ This is all the more significant as Mostashār al-Dawla evidently draws on Articles 8 and 10 of the French 1848 Constitution on the rights of citizens in formulating his Principle 2 and 7 . In the former, on the appointment of "individuals (ashkhās)" [corresponding to "citizens"] to governmental positions on the basis of merit. In the latter principle on freedom of association, the referent is omitted altogether (Pāshāzāda 2013/1392, 43-44).

${ }^{14}$ The one exception so far is the legalization of state-subsidized gender change operations.
} 
Arjomand, S.A., 1983. The Office of Mullā-bāshi in Shi ite Iran. Studia Islamica, 57, 13546.

Arjomand, S.A., 1984. The Shadow of God and the Hidden Imam: Religion, Political Organization and Societal Change in Shi ite Iran from the Beginning to 1890. University of Chicago Press.

Arjomand, S.A., 1988. The Turban for the Crown: The Islamic Revolution in Iran. Oxford University Press.

Arjomand, S.A., 1999. The Law, Agency and Policy in Medieval Islamic Society: Development of the Institutions of Learning from the Tenth to the Fifteenth Century. Comparative Studies in Society and History, 41(2), 263-93.

Arjomand, S.A., 2005. Political Ethic and Public Law in the Early Qajar Period. In: R. M. Gleave, ed., Religion and Society in Qajar Iran. London: Routledge Curzon, pp. 2140.

Arjomand, S.A., 2013. The Shi ite Jurists and Iran's Constitutional Order in the Twentieth Century. In: S.A. Arjomand and N.J. Brown, eds., The Rule of Law, Islam and Constitutional Politics in Egypt and Iran. Albany, NY: SUNY Press, pp. 15-56.

Arjomand, S.A., 2016. Unity of the Persianate World under Turko-Mongolian Domination and Divergent Development of Imperial Autocracies in the Sixteenth Century. Journal of Persianate Studies [online], 9(1), 1-18. Available from: https://doi.org/10.1163/18747167-12341292 [Accessed 3 May 2019].

Arjomand, S.A., forthcoming. The "King of Islam": An idea and its typological significance. In: N. Al-Baghdadi and S.H. Nasser, eds., [forthcoming]. Aziz alAzmeh Festschrift.

Astarābādi, M.K., 2015/1394. Tārikh-e jahāngoshā-ye nāderi. Tehran: Donya-ye Ketāb.

Bayāt, N., ed., 2004/1383. Gozida'yi az monsha'āt-e Mirzā Mahdi Khān Astarābādi. Tehran: Ministry of Foreign Affairs.

Doerfer, G., 1963-75. "No. 1789: yāsāq" in Türkische und mongolische Elemente im Neupersischen: unter besonderer Berücksichtigung alterer neupersischer Geschichtsquellen, vor allem der Mongolen- und Timuridenzeit (vol. 4). Wiesbaden: Steiner, 71-82.

Ettehadieh Nezam-Mafi, M., 1989. The Council for the Investigation of Grievances. Iranian Studies, 22(1), 51-61.

Floor, W., 2009. Judicial System from the Advent of Islam through the Nineteenth Century. Encyclopaedia Iranica [online], 15, 199-204. Available from: http://www.iranicaonline.org/articles/judicial-and-legal-systems-iv-judicialsystem-from-the-advent-of-islam-through-the-19th-century [Accessed 3 May 2019].

İnalcık, H., 2012. Ḳānūnnāme. In: P. Bearman et al., eds., Encyclopaedia of Islam, $2^{\text {nd }}$ ed. [online]. Originally published in 1978. Available from: http://dx.doi.org/10.1163/1573-3912 islam COM 0440 [Accessed 3 May 2019]. 
Kondo, N., 2017. Islamic Law and Society in Iran: A Social History of Qajar Tehran. London: Routledge.

Kondo, N., 2019. How to Found a New Dynasty: The Early Qajars' Quest for Legitimacy. Journal of Persianate Studies, 12.2.

Linant de Bellefonds, Y., Cahen, C., and İnalcık, H., 2012. Kānūn. In: P. Bearman et al. eds., Encyclopaedia of Islam. $2^{\text {nd }}$ ed. [online]. Originally published in 1978. Available from: http://dx.doi.org/10.1163/1573-3912 islam COM 0439 [Accessed 3 May 2019].

Manz, B.F., 1988. Tamerlane and the Symbolism of Sovereignty. Iranian Studies, 21.1-2, 105-22.

Mardin, Ş., 1962. The Genesis of the Young Ottoman Thought. A Study in the Modernization of Turkish Political Ideas. Redwood City, CA: Stanford University Press.

Mohit-Tabātabā'i, M., 1968/1347. Dādgostari dar Irān. [Published as an appendix to the journal, Vahid, Farvardin 1347 issue].

Morgan, D.O., 2005. The "Great Yasa of Chinggis Khan" Revisited. In: R. Amitai-Preiss and M. Biran, eds., Mongols, Turks, and Others: Eurasian Nomads and the Sedentary World. Leiden: Brill, pp. 291-308.

Mostashār al-Dawla, M.Y.K., 1985/1364. Yek Kalama. Tehran: Nashr-e Tārikh-e Irān.

Pāshāzāda, G., 2013/1392. Dar Jostoju-ye qānun. Zendagi o adnisha-ye Mirzā Yusof Khan Mostashār al-Dawla. Tehran: Nashr-e 'Elm.

Qāyeni, J.A.D.M.B. 'Ubaydollāh. Nasāyeh-e Shahrokhi. Vienna: Österreiche Nazionalbibliothek, MS \# ONVA10559.

Schneider, I., 2006. The Petitioning System in Iran. State, Society and Power Relations in the Late 19th Century. Wiesbaden: Harrassowitz.

Schneider, I., 2008. 'Izz al-Daula und die Hamaner: Qājārische Localpolitik im Spiegel der Petitionen an Nāsir al-Din Šāh (reg. 1848-1896). In: K. Lorenz, E. Ortmann and F. Schwarz, eds., Die Grenzen der Welt. Arabica et Iranica ad honorem Heinz Gaube. Wiesbaden: Reichert, pp. 223-41.

Shirāzi, Ebn 'Abdol-Karim, A.R., 1986. Tārikh-e Zandiyya (Jāneshinān-e Karim Khān Zand), Gh. Varahrām ed., Tehran: Nashr-e Gostarda. (The text being a reprint of Das Tārikh-I Zendije, Ernst Beer, ed., Leiden: Brill, 1888)

Werner, C., 2005a. Pious Merchants: Religious Sentiments in Wills and Testaments. In: R. M. Gleave, ed., Religion and Society in Qajar Iran. London: Routledge Curzon, pp. 211-26.

Werner, C., 2005b. Urf oder Gewohnheitsrecht in Iran: Quellen, Praxis und Begrifflichkeit. In: M. Kemper and M. Reinkowski, eds., Rechtspluralismus in der Islamischen Welt: Gewohnheitsrecht zwischen Staat und Gesellschaft. Berlin: Walter de Gruyter, pp. 153-75. 